\title{
Australian Carbonatites: Their Resources and Geodynamic Setting
}

\author{
A.L. Jaques \\ Geoscience Australia \\ GPO Box 378, Canberra, ACT, Australia 2601
}

\begin{abstract}
Carbonatites are known from each of the megacrustal elements comprising the Precambrian Australian Shield (Figure 1). Australian carbonatites are of interest because - like their counterparts elsewhere - they contain high abundances of LREE, Nb, Ta, $\mathrm{P}$ and, in a number of cases, $\mathrm{U}$. Current high prices for $\mathrm{U}$ and increased demand for REE (magnets, electronics, automobiles) have renewed exploration interest. Most of the carbonatites lie near major structural features evident in continent-scale aeromagnetic and gravity data and/or seismic tomographic models. The carbonatites fall into two types 1) those associated with kimberlite and/or ultramafic lamprophyres, and 2) carbonatites occurring in alkaline complexes or discrete bodies.
\end{abstract}

\section{Carbonatites within kimberlite fields}

The oldest confirmed Australian carbonatites - the 2020 Ma Mount Weld and Ponton Creek intrusions lie within the late Archean granite-greenstone terranes of the Eastern Goldfields of the Yilgarn Craton and form part of an alkaline suite including kimberlites and melnoites. Isotopic and trace element evidence suggest they were derived from metasomatised lithospheric mantle that may have also given rise to a contiguous belt of earlier 2.66 Ga syenites (Graham et al., 2004). All lie along a major structure in the lithosphere evident in regional seismic tomographic models.

The Mount Weld Carbonatite comprises an annulus of brecciated wall-rock and fenitic alteration surrounding a 3 km wide carbonatite (mostly sovite) plug (Duncan and Willett, 1990). The carbonatite is overlain by a thick regolith containing high grade rare earth oxide (REO) deposits and accumulations of apatite, and $\mathrm{Nb}$ and other 'rare metals'. The Mount Weld carbonatite hosts the world's richest lanthanide deposit with the central lanthanide deposit (CLD) containing 12.24 Mt @ 9.7\% REO (2.5\% REO cut off; Lynas Corp. Ltd, 2008). Open pit mining of the central high grade secondary monazite zone (4.7 Mt @ 13.8\% REO) is producing feedstock for concentration and shipping to Malaysia for processing with a view to producing 10,500t REO in 2009. In addition to the CLD Mount Weld hosts the southern ore zone containing $2.78 \mathrm{Mt}$ (a) 4.0\% REO (richer in HREE), and the Crown and Coors polymetallic deposits containing $\mathrm{Nb}, \mathrm{P}, \mathrm{REO}$, $\mathrm{Ta}, \mathrm{Zr}, \mathrm{Y}$ and Ti resources.

The Ponton Creek (Cundeelee) carbonatite is a major stock or plug $\sim 10 \mathrm{~km}$ across overlain by $500 \mathrm{~m}$ of
Permian tillite lying $\sim 200 \mathrm{~km}$ ESE of Mount Weld. Graham et al. (2004) included this body within the $\sim 2020$ Ma Eastern Goldfields alkaline suite. It has a central core of ultramafic cumulates (mostly olivinepyroxenite) cut by narrow veins of apatite-rich carbonatite. Peralkaline syenites are also associated.

Carbonatite veins have been reported from the Granny Smith and Wallaby gold mines, respectively $\sim 15 \mathrm{~km}$ NW and $\sim 28 \mathrm{~km} \mathrm{~W}$ of Mount Weld. Gold at both is associated with $\sim 2.66$ Ga monzodiorite-syenite stocks and dykes and carbonate-rich rocks. These include skarn and hydrothermally altered rocks, post-ore carbonatites and ultramafic lamprophyres (Granny Smith) correlated with the Mount Weld carbonatite, and disputed late-stage 'carbonatites' associated with 2.66 Ga syenites (Mueller et al., 2008).

The Yungal carbonatite dyke and the associated Speewah fluorite deposit lie near the major Greenvale Fault at the eastern margin of the Kimberley Craton and adjacent Paleoproterozoic Halls Creek Orogen in the North Australian Craton. The carbonatite is spatially associated with Neoproterozoic ( $\sim 800 \mathrm{Ma})$ kimberlites and lamprophyres, including the andraditecarbonate-bearing Bow Hill lamprophyre dyke (Jaques et al., 1986) but its intrusion age is unknown.

The Walloway carbonatite is part of suite of small dykes and plugs of carbonate-rich and chemically evolved kimberlite and ultramafic lamprophyre of Jurassic age ( 170 Ma) in the Orroroo (Euralia) region at the eastern margin of the Gawler Craton in South Australia (Tucker and Collerson, 1972; Ferguson and Sheraton, 1979). Walloway has similar $\mathrm{C}, \mathrm{Nd}$ and $\mathrm{Pb}$ isotopic compositions to carbonatites elsewhere but more radiogenic Sr and heavier O (Nelson et al., 1988).

\begin{abstract}
Alkaline provinces and discrete complexes
Other carbonatites are either spatially separate or differ in age from known kimberlite fields. Most are associated with other alkaline igneous activity.
\end{abstract}

The Copperhead 'carbonatite' which intrudes the Paleoproterozoic Halls Creek Orogen consists of a small alkaline intrusion with a syenite core and fenitised syenite outer zone containing localised 'carbonatite' breccia pods (Rugless and Pirjano, 1996). Recent U-Pb dating indicates it was emplaced at $\sim 1821$ $\mathrm{Ma}$ and thus predates the Neoproterozoic suite of kimberlites and lamprophyres in the region. 


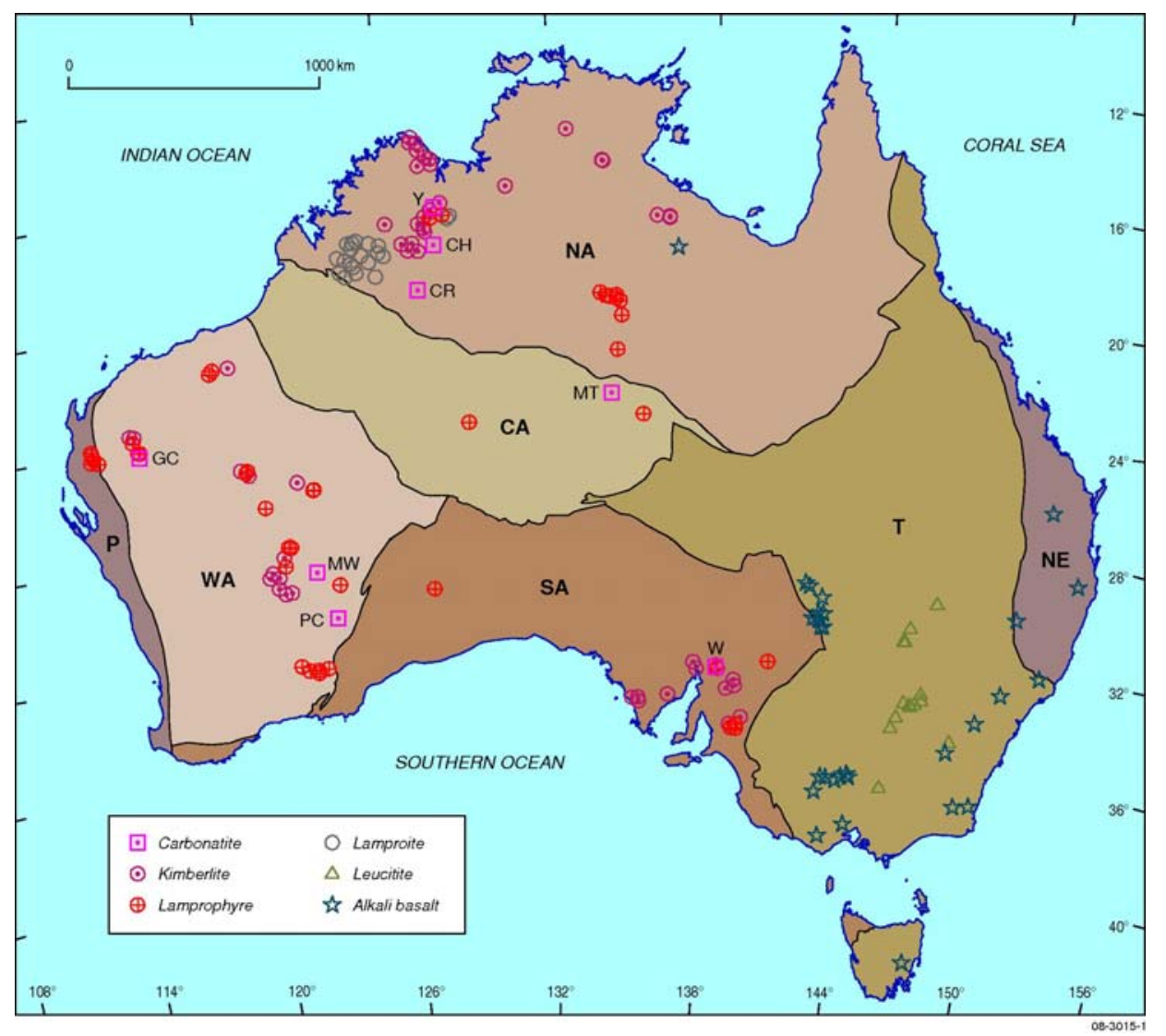

Figure 1. Simplified map showing distribution of Australian carbonatites in relation to kimberlites, lamprophyres, and other alkaline igneous rocks and the crustal mega-elements. WA, NA, CA, and SA refer to the west, north, central and southern Australian mega-elements, $\mathrm{T}=$ Tasman, $\mathrm{NE}=$ New England. Carbonatites shown are Copperhead $(\mathrm{CH})$, Cummins Range (CR), Gifford Creek (GC), Mud Tank (MT), Mount Weld (MW), Ponton Creek (PC), Walloway (W), and Yungal (Y). A map at 1:5 million scale is available online (Jaques, 2008).

The Cummins Range Carbonatite lies at the southern margin of the Halls Creek Orogen surrounding the Kimberley craton. The carbonatite comprises a composite, zoned sub-vertical vertical stock $\sim 2 \mathrm{~km}$ across with a central carbonatite core and an eastern plug of carbonated mica pyroxenite (Andrew, 1990). Isotopic dating (1012 $\pm 12 \mathrm{Ma} \mathrm{U}-\mathrm{Pb}$ zircon and $905 \pm 2$ $\mathrm{Ma} \mathrm{Rb}-\mathrm{Sr}$ ) indicates that the carbonatite pre-dates the $\sim 800$ Ma kimberlites of the North and East Kimberley regions but may be coeval with the Bow Hill lamprophyre (Jaques et al., 1986). An enriched regolith zone over the carbonatite and the pyroxenite phases hosts REO, $\mathrm{U}, \mathrm{Nb}$ and $\mathrm{P}$ mineralisation. Recent company drilling has outlined a resource of $3.55 \mathrm{Mt}$ (1\% REO cut-off) @ 2.0\% REO, 11.2\% $\mathrm{P}_{2} \mathrm{O}_{5}, 216$ ppm $\mathrm{U}_{3} \mathrm{O}_{8}$ and 36 ppm Th. Included within this is a higher grade zone (+2\% REO cut-off) of 1.1 Mt @ 3.5\% REO and a partially overlapping zone of 1.3 Mt @ 414 ppm $\mathrm{U}_{3} \mathrm{O}_{8}$ (Navigator Resources Ltd, 2008). Economically significant levels of $\mathrm{Nb}, \mathrm{Ta}, \mathrm{Zr}, \mathrm{Ti}$ and $\mathrm{Th}$ have also been reported.

The Mesoproterozoic Gifford Creek alkaline complex in the Gascoyne Complex of the Capricorn Orogen of WA lies $\sim 70 \mathrm{~km}$ south of the Barlee Range field of kimberlites and lamprophyres (see Jaques, 2008). The complex comprises an older $(\sim 1.68 \mathrm{Ga})$ swarm of ultrabasic sills accompanied by a extensive belt of fenite that have affinities with carbonate-rich kimberlites and ultramafic lamprophyres, and a later $(\sim 1.25 \mathrm{Ga})$ set of REE-bearing ferrocarbonatemagnetite-hematite dykes (Yangibana ironstones) and other magnetite-bearing alkaline rocks (Pearson and Taylor, 1996).

The 732 Ma Mud Tank Carbonatite lies within the Strangways alkaline igneous province in central Australia (Figure 1). It occurs as a series of carbonaterich lenses surrounded by mica-rich zones and was emplaced into granitoid cataclasites, and mafic aluminous granulites at mid-crustal levels in a active ductile shear zone and remobilised, with part of its $\mathrm{Na}$ rich metasomatic aureole, to higher crustal levels (Currie et al., 1992). Vermiculite is mined at Mud Tank with 8,900t produced in 2006/07. Mud Tank is also a source of gem quality zircon.

Carbonate-rich vein and dykes occur in the $1130 \mathrm{Ma}$ Mordor Igneous Complex. $50 \mathrm{~km}$ SSE of the Mud Tank carbonatite. This alkaline complex comprises fractionated suite of co-magmatic alkaline felsic and mafic rocks (syenite-monzonite-shonkinite) and spatially associated phlogopite-bearing ultramafic rocks. Apart from being significantly older than the Mud Tank Carbonatite the Mordor Complex has distinctly more radiogenic $\mathrm{Sr}$ isotopic compositions 
than the carbonatite (Black and Gulson, 1978). Both however are located on the Woolanga Lineament, a deep seated NW-trending crustal structure that appears to have controlled the emplacement of alkaline rocks in this province throughout much of the Proterozoic.

\section{Implications}

The distribution of kimberlites, lamproites and other related alkaline volcanics in Australia is related to the structure of the lithosphere with many intrusions located on discontinuities and gradients evident in continent-scale seismic tomography and potential field data (Jaques and Milligan, 2004). The known carbonatites lie near the margins of cratons and in most provinces there is evidence of deep crustal (and potentially lithospheric) structures that control the distribution of carbonatites and potentially other alkaline suites. Some of these structures have been active over extended periods of time with multiple intrusion events. The geodynamic setting for most is uncertain and may be controlled by far-field stresses. Some may be related to extension events: for example, the Mud Tank carbonatite may have been emplaced during development of the Neoproterozoic Amadeus Basin. Emplacement of the Cummins Range Carbonatite may, as has been suggested for the Neoproterozoic kimberlites in Northern Australia, be linked to structures associated with the break-up of Rodinia (Jaques and Milligan, 2004).

Available trace element and isotopic data for the carbonatites and their co-magmatic counterparts are consistent with derivation as small volume melts from asthenospheric mantle and/or refertilised subcontinental lithospheric mantle (Nelson et al., 1988; Graham et al. 2004). An apparent lack of association between Australian carbonatites and kimberlites carrying economic grades of diamonds suggests that the fluids associated with the refertilisation process were hostile to diamond preservation and/or that these kimberlites were derived from relatively shallow levels in the mantle.

Australian carbonatites, like those elsewhere, have intrinsically high abundances of REE as well as other large-ion-lithophile elements and high-field strength elements such as $\mathrm{Nb}$ and $\mathrm{Ta}$. However, economic and potentially-economic concentrations of REO, $\mathrm{U}, \mathrm{P}, \mathrm{Nb}$, Ta and other 'rare metals' in the regolith developed over the carbonatites result from supergene enrichment. Weathering with pronounced vertical and lateral groundwater flow resulted in leaching and dissolution with enrichment in resistate minerals and formation of secondary REE-rich phosphates and aluminophosphates under conditions of high fluid/rock ratios, long fluid rock residence times, and a range of pH and alkalinity conditions (Lottermoser, 1990).

\section{References}

Andrew, R.L., 1990. Cummins Range carbonatite. In: Hughes, F.E. (Ed.), Geology of the Mineral Deposits of Australia and Papua New Guinea, 711-713. The Australian Institute of Mining and Metallurgy, Melbourne.

Black, L.P., Gulson, B.L., 1978. The age of the Mud tank Carbonatite, Strangways range, Northern Territory. BMR Journal of Australian Geology \& Geophysics, 3, 227-232.

Currie, K.L.; Knutson, J., Temby, P.A., 1992. The Mud Tank carbonatite complex, central Australia; an example of metasomatism at mid-crustal levels. Contributions to Mineralogy and Petrology, 109, 326-339.

Duncan, R.K., Willett, G.C., 1990. Mount Weld Carbonatite. In: Hughes, F.E. (Ed.), Geology of the Mineral Deposits of Australia and Papua New Guinea, 591597. The Australian Institute of Mining and Metallurgy, Melbourne.

Ferguson, J., Sheraton, J.W., 1979. Petrogenesis of kimberlitic rocks and associated xenoliths of Southeastern Australia. In: Boyd, F.R., Meyer, H.O.A. (Eds). Kimberlites, Diatremes and Diamonds: their Geology, Petrology, \& Geochemistry, 140-160. American Geophysical Union, Washington. D.C.

Graham, S., Lambert, D., Shee, S., 2004. The petrogenesis of carbonatite, melnoite and kimberlite from the Eastern Goldfields Province, Yilgarn Craton. Lithos 76, 519-533.

Jaques, A.L., 2008. Australian diamond deposits, kimberlites and related rocks 1:5 000000 scale map. Geoscience Australia. http://www.ga.gov.au/image_cache/GA11247.pdf

Jaques, A.L., Lewis, J.D., Smith, C.B., 1986. The Kimberlites and Lamproites of Western Australia. Geological Survey of Western Australia Bulletin 132.

Jaques, A.L., Milligan, P.R., 2004. Patterns and controls on the distribution of diamondiferous intrusions in Australia. Lithos, 77, 783-802.

Lottermoser, B., 1990. Rare-earth element mineralisation within the Mt. Weld carbonatite laterite, Western Australia. Lithos, 24, 151-167.

Lynas Corporation Ltd, 2008. Quarterly Report to the ASX, March 2008.

Mueller, A.G., Hall, G.C., Nemchin, A.A., Stein, H.R., Creaser, R.A., Mason, D.R., 2008. Archaean high-Mg monzodiorite-syenite, epidote skarn, and biotitesericite gold lodes in the Granny Smith-Wallaby district, Australia: U-Pb and Re-Os chronometry of two intrusion-related hydrothermal systems. Mineralium Deposita, 43, 337-362.

Navigator Resources Ltd, 2008. March Report to the ASX.

Nelson, D.R., Chivas, A.R., Chappell, B.W., McCulloch, M.T., 1988. Geochemical and isotopic systematics in carbonatites and implications for the evolution of ocean-island sources. Geochimica et Cosmochimica Acta, 52, 1-17.

Pearson, J.M., Taylor, W.R., 1996. Mineralogy and chemistry of fenitized alkaline ultrabasic sills of the Gifford Creek Complex, Gascoyne Province, Western Australia. The Canadian Mineralogist, 34, 201-219.

Rugless, C.S., Pirjano, F., 1996. Geology and geochemistry of the Copperhead albitite 'carbonatite' complex, east Kimberley, Western Australia. Australian Journal of Earth Sciences, 43, 311-322.

Tucker, D.H., Collerson, K.D., 1972. Lamprophyric intrusions of probable carbonatitic affinity from South Australia. Australian Journal of Earth Sciences, 19, 387-391. 